Hydrogeology of the Uppermost Confined Aquifers Underlying the Hanford Reservation

Rodney K. Ledgerwood

Raul A. Deju

March 1976

Prepared for the U.S. Energy Research

and Development Administration

Under Contract E(45-1)-2130

Atlantic Richfield Hanford Company

Richland, Washington 99352

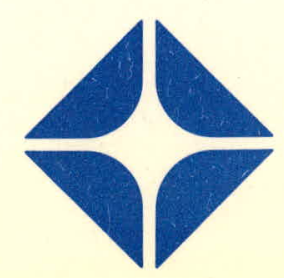




\section{DISCLAIMER}

This report was prepared as an account of work sponsored by an agency of the United States Government. Neither the United States Government nor any agency Thereof, nor any of their employees, makes any warranty, express or implied, or assumes any legal liability or responsibility for the accuracy, completeness, or usefulness of any information, apparatus, product, or process disclosed, or represents that its use would not infringe privately owned rights. Reference herein to any specific commercial product, process, or service by trade name, trademark, manufacturer, or otherwise does not necessarily constitute or imply its endorsement, recommendation, or favoring by the United States Government or any agency thereof. The views and opinions of authors expressed herein do not necessarily state or reflect those of the United States Government or any agency thereof. 


\section{DISCLAIMER}

Portions of this document may be illegible in electronic image products. Images are produced from the best available original document. 


\section{Atlantic Richfield Hanford Company \\ Richland, Washington 99352}

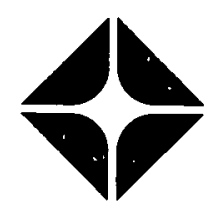

NOTICE

THIS REPORT WAS PREPARED AS AN ACCOUNT OF WORK SPONSORED BY THE UNITED STATES GOVERNMENT. NEITHER THE UNITED STATES NOR THE UNITED STATES ENERGY RESEARCH AND DEVELOPMENT ADMINISTRATION, NOR ANY OF THEIR EMPLOYEES, NOR ANY OF THEIR CONTRACTORS, SUBCONTRAGTRRS, OR THEIR EMPLOYEES, MAKES ANY WARRANTY, EXPRESS OR IMPLIED, OR ASSUMES ANY LEGAL LIABILITY OR RESPONSIBILITY FOR THE ACCURACY, COMPLETENESS, OR USEFULNESS OF ANY INFORMATION, APPARATUS, PRODUCT OR PROCESS DISCLOSED, OR REPRESENTS THAT ITS USE WOULD NOT INFRINGE PRIVATELY OWNED RIGHTS. 


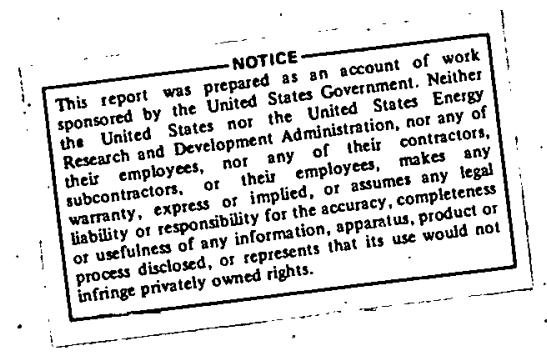

\title{
HYDROGEOLOGY OF THE UPPERMOST CONFINED AQUIFERS UNDERLYING THE HANFORD RESERVATION
}

\author{
Rodney $K$. Ledgerwood \\ Ràl A. Deju \\ Groundwater Management section \\ Research Department \\ Research and Engineering Division \\ March 1976
}

\section{ATLANTIC RICHF IELD HANFORD COMPANY}

RICHLAND, WASHINGTON 99352

To be presented at the

Geological Society of America

Pullman, Washington

April 5, 1976 


\section{TABLE OF CONTENTS}

Page

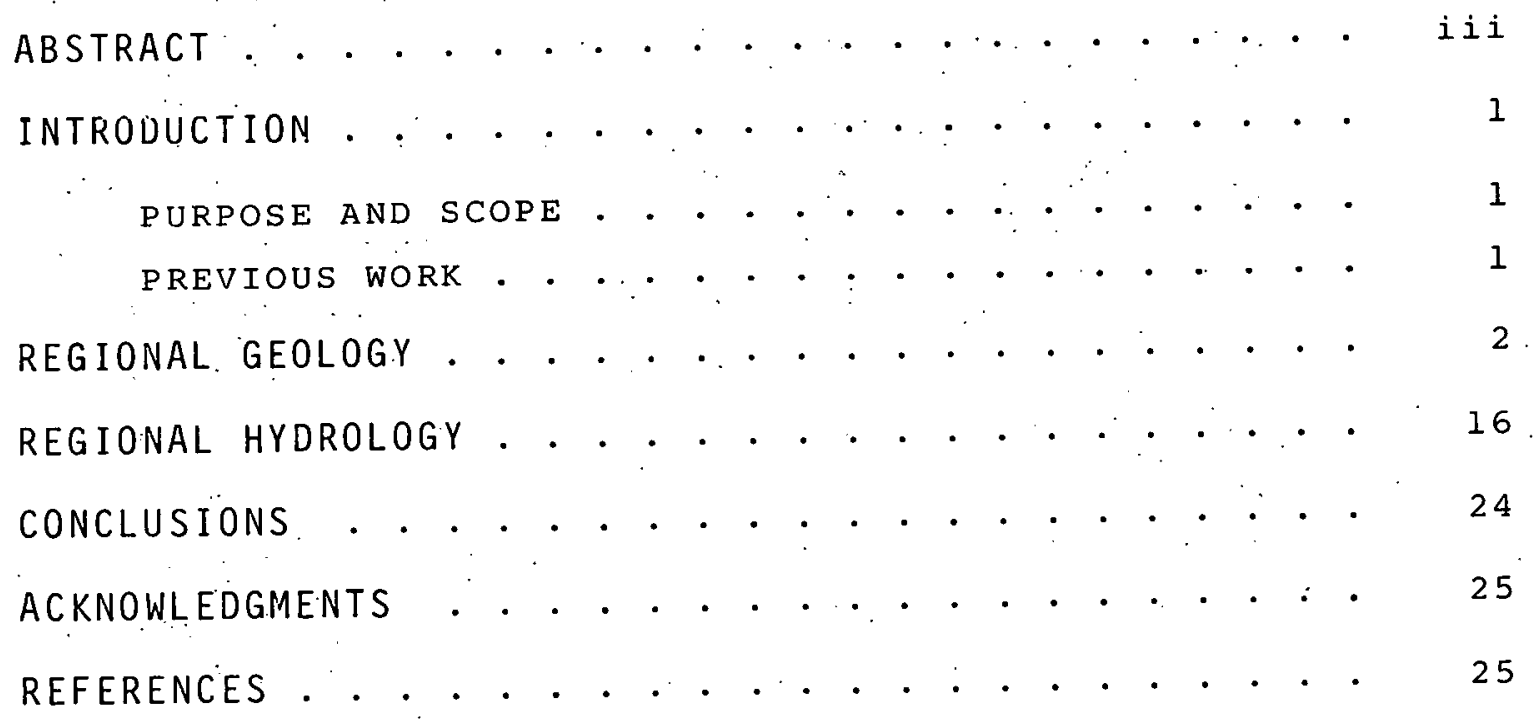




\section{ABSTRACT}

This paper discusses the regional geology and hydrology of the Hanford Reservation with emphasis. on the characteristics of the Lower Ringold Formation and the Columbia River Basalts and interbeds. These formations constitute the uppermost confined flow systems underlying the Hanford Reservation. Work shown in this paper leads to the conclusion that these aquifers are rather extensive and that they are interconnected especialiy along the Umtanum-Gable Anticiine. Recharge into the confined aquifers appears to occur at the fringes of: the Pasco Basin. The eastern portion of the Hanford Reservation appears to be a discharge area for these aquifers. Areas of monoclinal downfolding such as cold creek Valzey appear to act as flow barriers, thus helping to build up the pressure in the uppermost confined aquifers. 


\title{
HYDROGEOLOGY OF THE UPPERMOST CONFINED AQUIFERS \\ UNDERLYING THE HANFORD RESERVATION
}

\author{
INTRODUCTION
}

PURPOSE AND SCOPE

This paper discusses the regional geology and hydrology of the uppermost confined flow system underlying the Hanford Reservation. This flow system is composed of several aquifers, primarily interbeds of the Columbia River Basalts.

The interconnection of the uppermost confined flow system and the overlying unconfined aquifer is also examined in detail.

The purpose of this paper is to describe the setting of the uppermost confined aquifers, and their interconnection to the overlying unconfined flow system. Such work is needed in order to assess the extent of potential cross-flow between the uppermost confined aquifers and the unconfined aquifer underlying the Hanford Reservation.

\section{PREVIOUS WORK}

Newcomb [1] and Newcomb et al. [2] have studied the tectonics and regional geology of the Columbia River Flood Basalts. They have also conducted a preliminary assessment of the extent of recharge into the uppermost confined aquifers.

R. E. Brown ${ }^{[3]}$ has studied the Columbia River Basalts and assessed the rates of their deformation in the pasco Basin.

Fenix \& Scisson, Inc., prepared drill-hole information 
on core wells and test holes penetrating the uppermost confined aquifers. [4-7]

Lasala et $a \dot{l}$. [8] have studied the deeper confined aquifers underlying the Hanford Reservation.

Deju[9] and Summers and Deju[1 0 ] interpreted the results of pumping tests into the uppermost confined aquifers and discussed the geohydrology of the overlying unconfined aquifer.

The U. S. Energy Research and Development Administration [ [1]] has summarized some of the hydrologic data on the uppermost confined aquifers as part of the Environmental Statement of Hanford Waste Management operations.

All the above reports, published data, and new data gathered by the authors have been used in preparing this report.

\section{REGIONAL GEOLOGY}

:The Hanford Reservation (Figure 1) is located in southcentral washington in the Pasco Basin. which is a physio-" graphic and structural subdivision of the Columbia River geologic province. The Reservation is bounded by the Columbia River to the north and east; the Yakima River and the City of Richland to the south; and the cold Creek Valley, Umtanum Ridge, Yakima Ridge, and the Rattlesnake Hills to the west. The Reservation is underlain by Miocene and Pliocene basalts of the Columbia River group, Pliocene. and Pleistocene semiconsolidated-to-consolidated sands, silts, and gravels (Ringold Formation), and Quaternary glaciofluviatile and eolian sediments. The stratigraphy of the Pasco Basin in the vicinity of the Hanford Reservation 


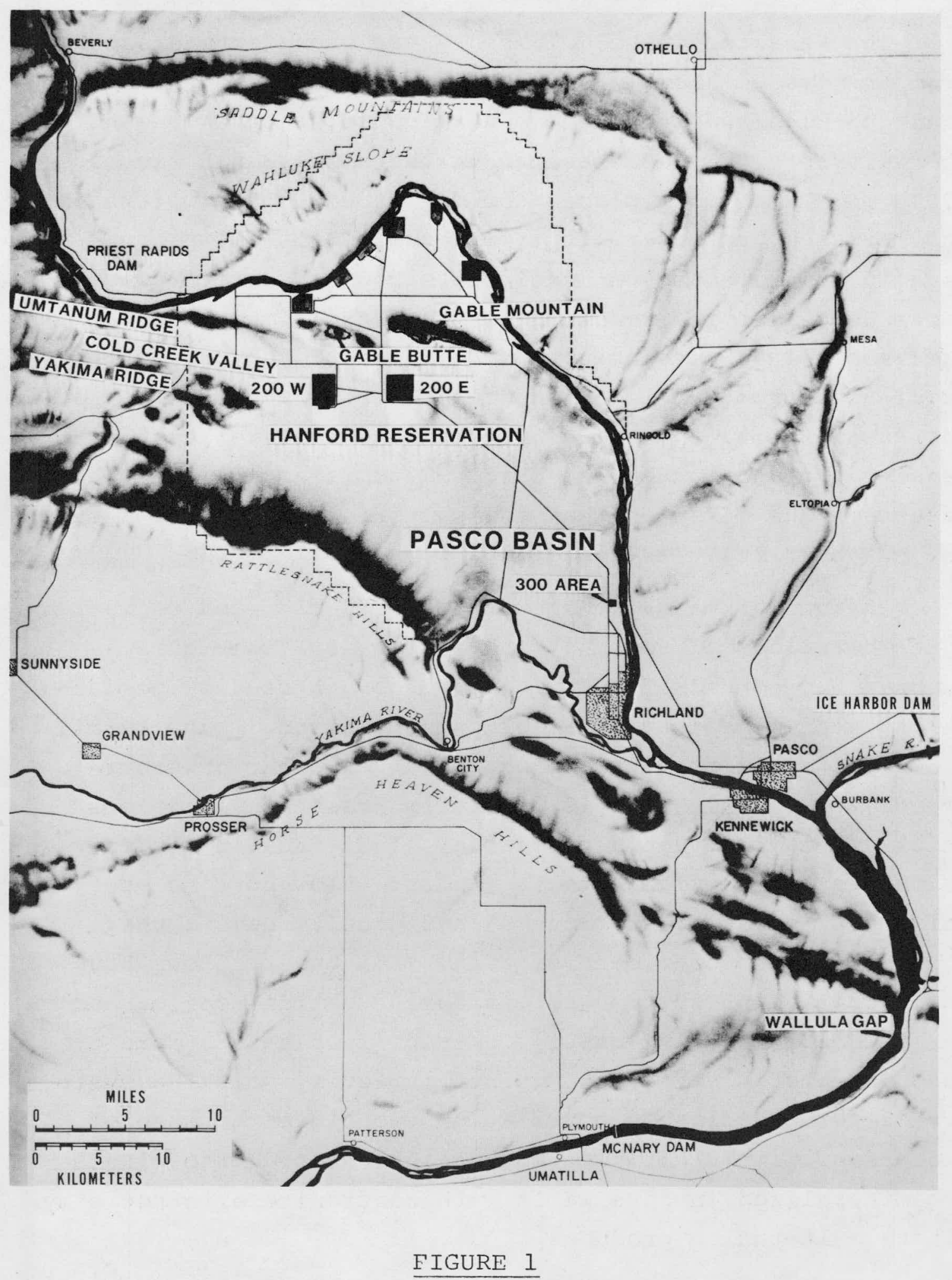

THE SETTING OF THE PASCO BÁSIN 
is summarized in Table I.

The basalts of the Columbia River group extend eastward: from the Cascade Range to the Rocky Mountains and from the okanogan Highlands into the mountains of central oregon. The thickness of. these basalts in the Pasco Basin exceeds 1,500 meters in most places and may exceed 3,000 meters in many areas. The uppermost individual basalt flows are usually separated by permeable interbeds or interflow sediments deposited in lacustrine or fluviatile environs between successive lava outpourings. The flows proper probably originated from multiple fissures to the south and east of the Pasco Basin. [12] Dikes feeding the most recent flows have been found in the Ice Harbor-Eltopia area. [13] The effect of the dikes on the regional groundwater flow system has not been fully evaluated.

Individual basalt members have differing and characteristic petrological compositions. However, individual members may contain flow units that cannot readily be differentiated except by stratigraphic position. Many basalt flow tops are marked by a pronounced vesicular or scoriaceous zone. This zone is generally less than 10 meters thick and may be highly permeable. Individual flows vary in thickness but may range to 50 meters. Flow bottoms are seldom vesicular or scoriaceous and usually have a chill zone only a few centimeters thick. All basalt flows have individual joint systems formed during solidification and shrinkage of the lava mass. Certain flows have a more or less diagnostic pattern of joints; however, jointing systems do not form a reliable correlation technique because of exceptions within a flow. Most joint and fracture planes are mineralized in core wells with nontronite or other clay mineral alteration products. 


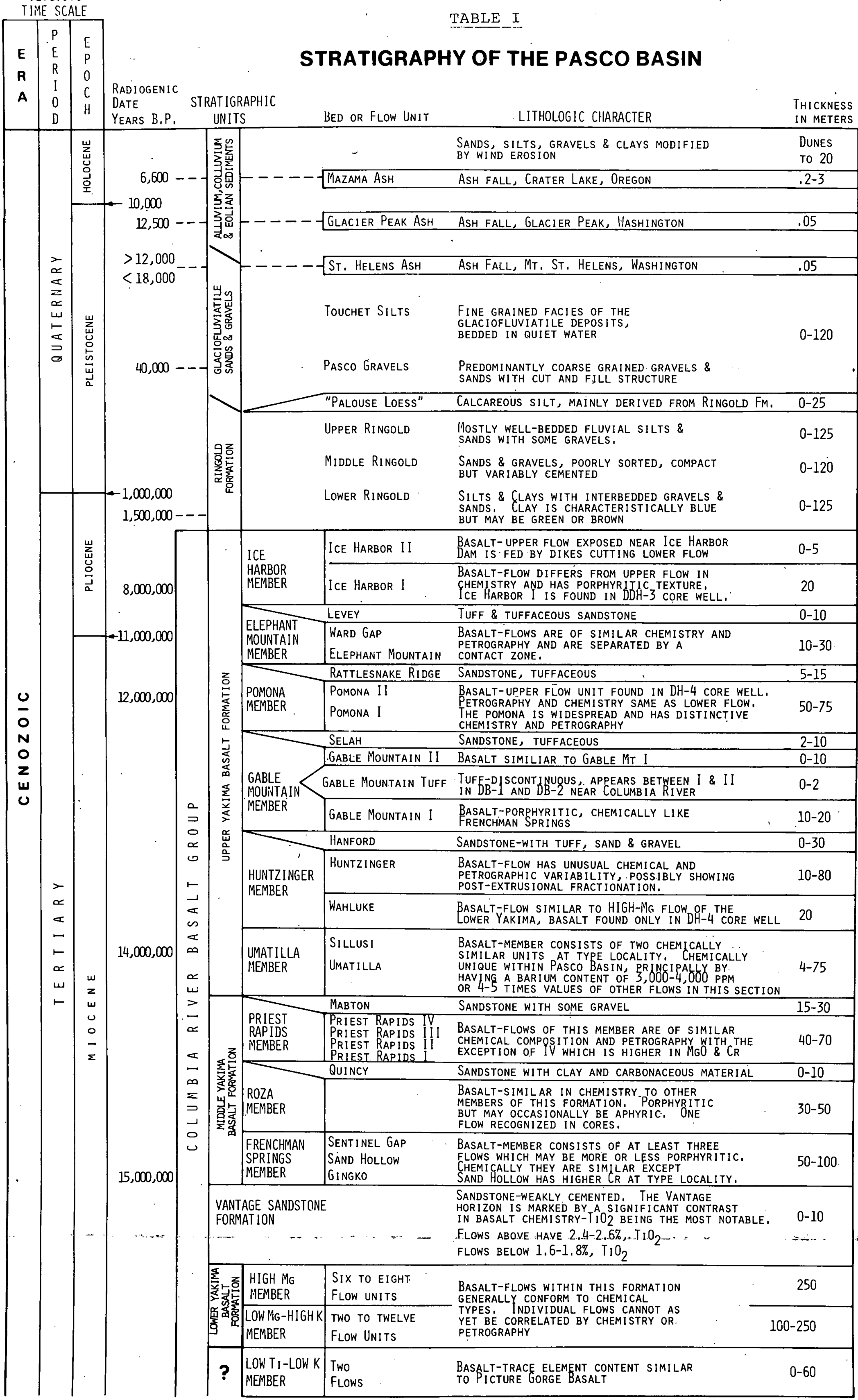


The structural and stratigraphic relationship of the uppermost basalt flows beneath the Hanford Reservation is extremely complex. This is probably a result of warping and basining and is especially visible along the Umtanum-Gable Anticline (Figure 2). Some of the early anticlinal structures such as Um'tanum Ridge probably acted as barriers to the most recent basalt flows and thus these flows occur in an off-lap relationship. Such structural traps produced restricted interbeds of clastic sediments which were later confined by overflowing flood basalts.

Warping and basining of the region has occurred during and after extrusion of individual flows forming southeastto-east trending anticlinal ridges and synclinal sub-basins. The principal anticline runs from Umtanum Ridge through both Gable Butte and Gable Mountain and separates the Cold Creek and the Pasco Synclines (Figure 2)'. The presence of these synclinal sub-basins has been confirmed by a recent regional gravity survey.[14] Interbeds of mostly subaqueous sands, tuffs, and local gravels are associated with both the Pasco and Cold Creek Synclinal sub-basins. Few interbeds can be traced for large distances.

Faults are largely restricted to the anticlinal ridges. Cross-faults mapped on Gable Mountain and Gable Butte have not been confirmed by extensive trenching. [15] Faulting in this area was shown to be minor and appears to have been associated with anticlinal flexures.

The Columbia River Basalts are overlain by the Ringold Formation (Table I). Newcomb et az. [2] have noted that deposition of the Ringold Formation started when the Columbia River was impounded in Middle Pleistocene time by the first uplift of the Horse Heaven Hills (Figure 1). A study by the authors of the stratigraphic relationships of 

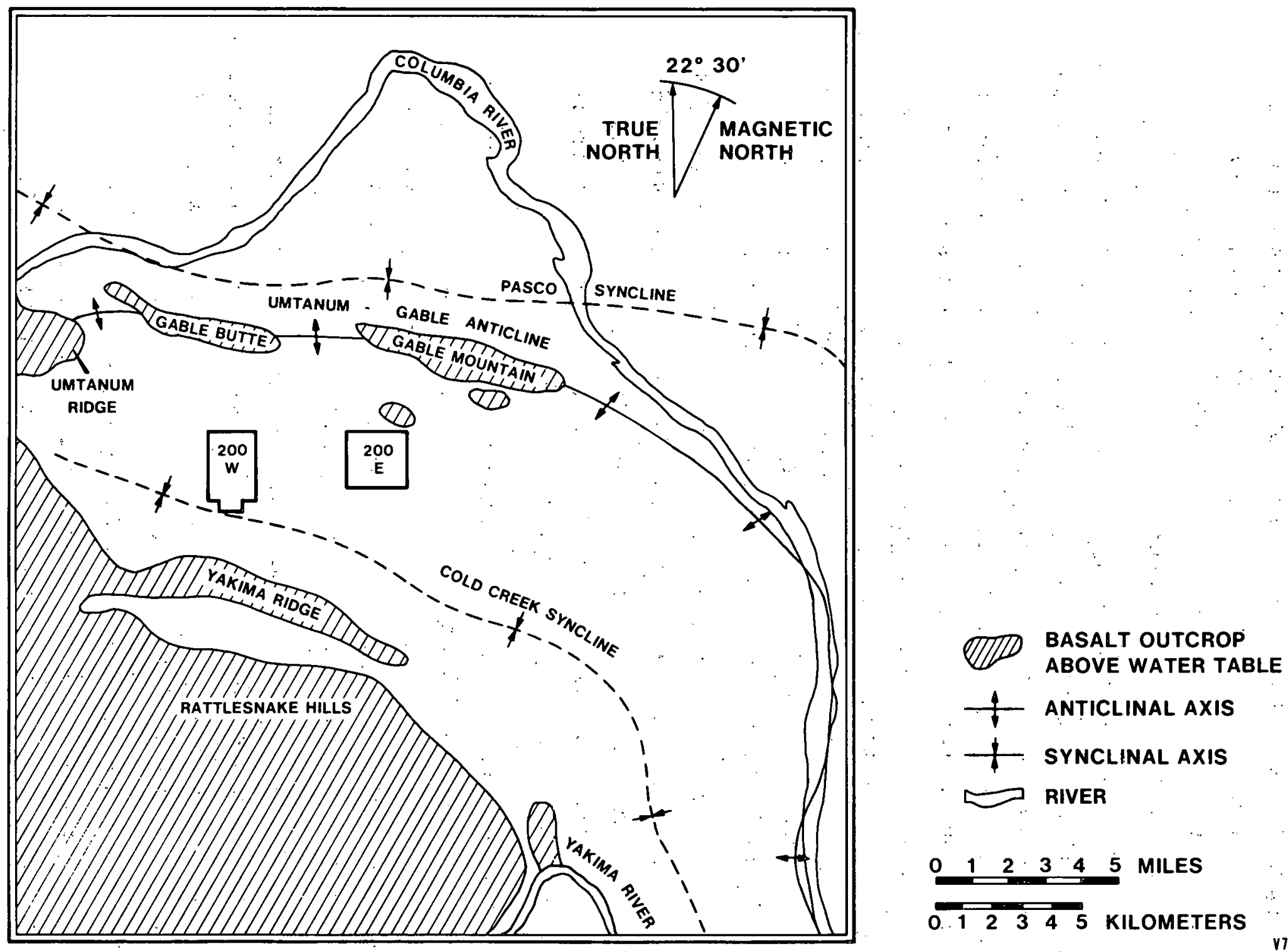

V7603-8.2 
the uppermost basalt flows exposed at Wallula Gap shows some evidence of uplift of this barrier prior to Pleistocene time. Thus, it appears likely that the Ringold Formation could be older than Pleistocene.

The Ringold Formation is as much as 400 meters thick in places and is characterized by well-bedded lacustrine silts and sands and local beds of clay and gravel. It is well sorted and shows some cementing. A slight warping-type of deformation characterizes the conglomerate and subconglomerate portions of the Ringold Formation in the basinal area beneath the Hanford Reservation. This uplift was followed by periods of active erosion and deposition of pleistocene glaciofluviatile and fluviatile deposits laid by the ancestral Columbia River as i.t swelled with meltwater.

The uppermost confined aquifers underlying the Hanford Reservation are the sands and gravels of the Lower Ringold Formation and the Rattlesnake Ridge, Selah, Hanford, and Mabton Interbeds. The primary source of geologic information on these aquifers is well data.

Figure 3 shows the wells within the Hanford Reservation and immediately adjacent to it that have been used in preparing this paper. Physical data from each well are contained in Tables II through IV. These wells include monitoring structures and core wells. [4-7]

Figures 4, 5, and 6 show three cross sections across portions of the Hanford Reservation (see Figure 3 for cross section locations), and illustrate the stratigraphic relationship of the various units.

Figure 4 shows a northwest-southeast trending cross section through the gap between Gable Butte and Gable Mountain. This figure clearly shows the Umtanum-Gable 


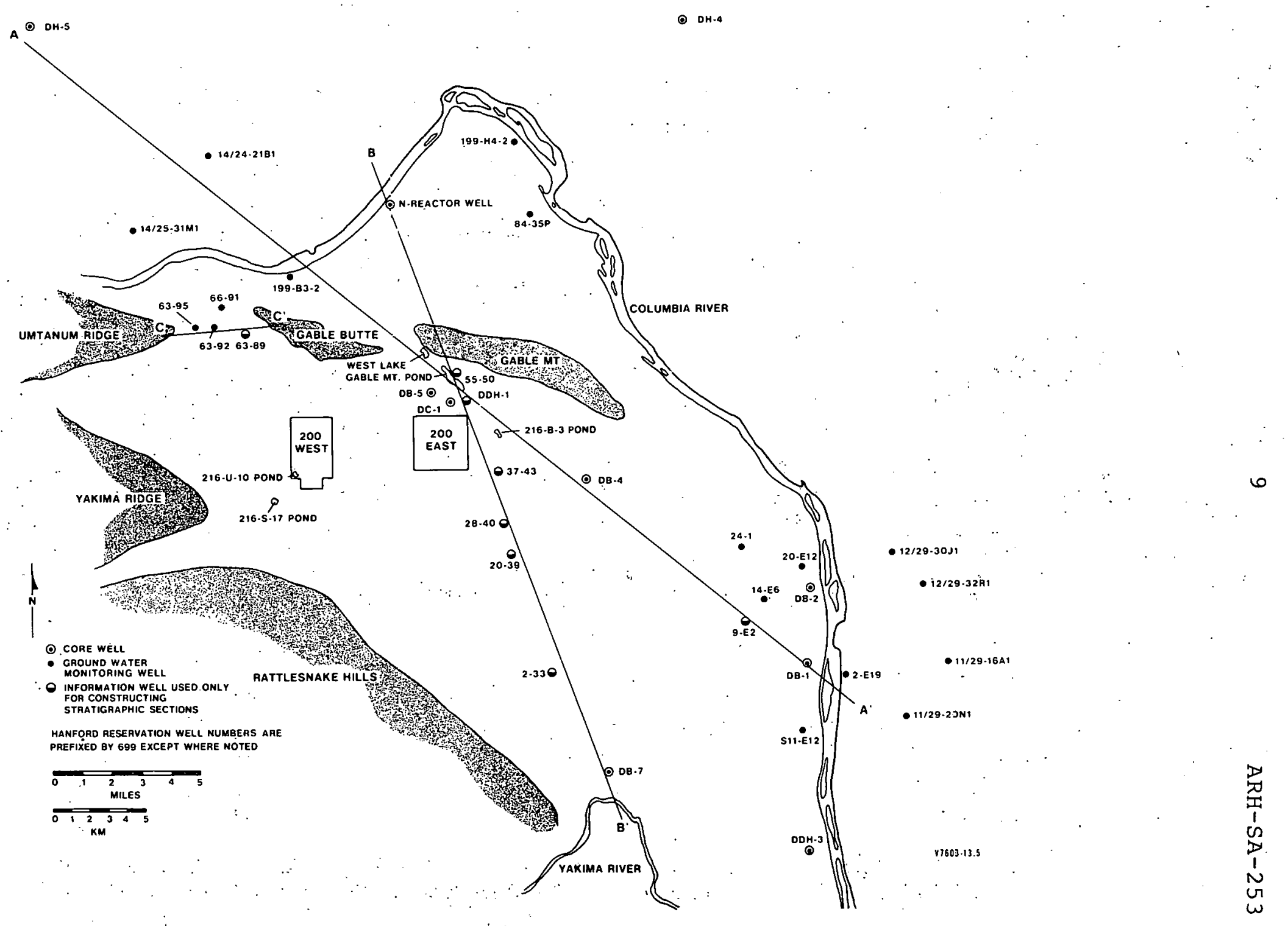

FIGURE 3.

WELL LOCATIONS 
TABLE II

WELLS WITHIN THE HANFORD RESERVATION SUITABLE FOR HEAD MEASUREMENTS AND CHEMICAL SAMPLING (REFER TO FIGURE 3 FOR WELL LOCATIONS)

\begin{tabular}{|c|c|c|c|c|c|c|c|c|c|c|c|c|}
\hline \multirow[b]{2}{*}{$\begin{array}{l}\text { We } 11 \text { Number } \\
199-B 3-2-(Q) \\
699-S 11-E 12 P \\
699-2-E 19 \\
699-14-E 6 R \\
699-19-E 12(P) \\
699-24-1 P \\
699-84-35(P)\end{array}$} & \multirow{2}{*}{$\begin{array}{r}\text { Open Interval } \\
\text { Meters Below } \\
\text { Ground Surface } \\
\begin{array}{l}193-196 \\
66-86 \\
84-88 \\
115-118\end{array}\end{array}$} & $\begin{array}{r}\text { Open } \\
\text { Meters Above } \\
\text { Mean Sea } \\
\end{array}$ & $\begin{array}{l}\text { n Interv } \\
\text { e }(+) \text { or } \\
\text { a Level } \\
\end{array}$ & \multicolumn{2}{|c|}{$\begin{array}{l}\text { Below (-) } \\
\text { (MSL) }\end{array}$} & \multicolumn{2}{|c|}{$\begin{array}{c}\text { Unconfined Water } \\
\text { (Above MSL in Metters) } \\
\text { December } 1975 \\
\end{array}$} & \multicolumn{2}{|c|}{$\begin{array}{c}\text { Confined Aquifer Head } \\
\text { (Above MSI in Metters) } \\
\text {-December } 1975 \\
\end{array}$} & \multicolumn{3}{|c|}{ well open to } \\
\hline & & $\begin{array}{l}(-) \\
(+) \\
(+) \\
(+) \\
(+) \\
(+) \\
(+)\end{array}$ & $\begin{array}{l}58-61 \\
47-26 \\
33-29 \\
25-22 \\
34-26 \\
9-\quad 6 \\
23-15\end{array}$ & & 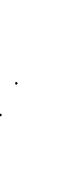 & $\begin{array}{l}122 \\
106 \\
107 \\
112 \\
109 \\
114 \\
114\end{array}$ & & $\begin{array}{l}122 \\
106 \\
107 \\
112 \\
109 \\
114 \\
114\end{array}$ & - & $\begin{array}{l}\text { Lower } \\
\text { Lower } \\
\text { Lower } \\
\text { Lower } \\
\text { Lower } \\
\text { Lower } \\
\text { Lower }\end{array}$ & $\begin{array}{l}\text { Ringold } \\
\text { Ringolo } \\
\text { Ringold } \\
\text { Ringolo } \\
\text { Ringolo } \\
\text { Ringolo } \\
\text { Ringolc }\end{array}$ & \\
\hline & $\begin{array}{r}231-237 \\
111-118 \\
134-138 \\
45-57 \\
23-62\end{array}$ & $\begin{array}{c}(-) \\
(+) \\
(+) \\
(+) \\
(+) \\
+1\end{array}$ & $\begin{array}{rr}96-102 \\
16-\quad 9 \\
6-\quad 2 \\
107-95 \\
125-86\end{array}$ & & & $\begin{array}{l}122 \\
114 \\
112 \\
122 \\
122\end{array}$ & ${ }^{\prime}$. & $\begin{array}{l}123 \\
127 \\
118 \\
122 \\
125\end{array}$ & 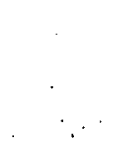 & $\begin{array}{l}\text { Rattle } \\
\text { Rattle } \\
\text { Rattle } \\
\text { Rattle } \\
\text { (or }\end{array}$ & $\begin{array}{l}\text { lake } \\
\text { rake } \\
\text { rake } \\
\text { zake }\end{array}$ & $\begin{array}{l}\text { Ridge } \\
\text { Ridge } \\
\text { Ridge } \\
\text { Ridge }\end{array}$ \\
\hline 699-66-91. & $30-58$ & $(+)$ & $113-85$ & $\cdot$ & & 122 & & 122 & & Rattle & esnake i & \\
\hline
\end{tabular}




\section{TABLE III}

CORE WELLS SUITABLE FOR HEAD MEASUREMENTS AND CHEMICAL SAIPLING WITHIN THE HANFORD RESERVATION (REFER TO FIGURE 3 FOR WELL'LOCATIONS)

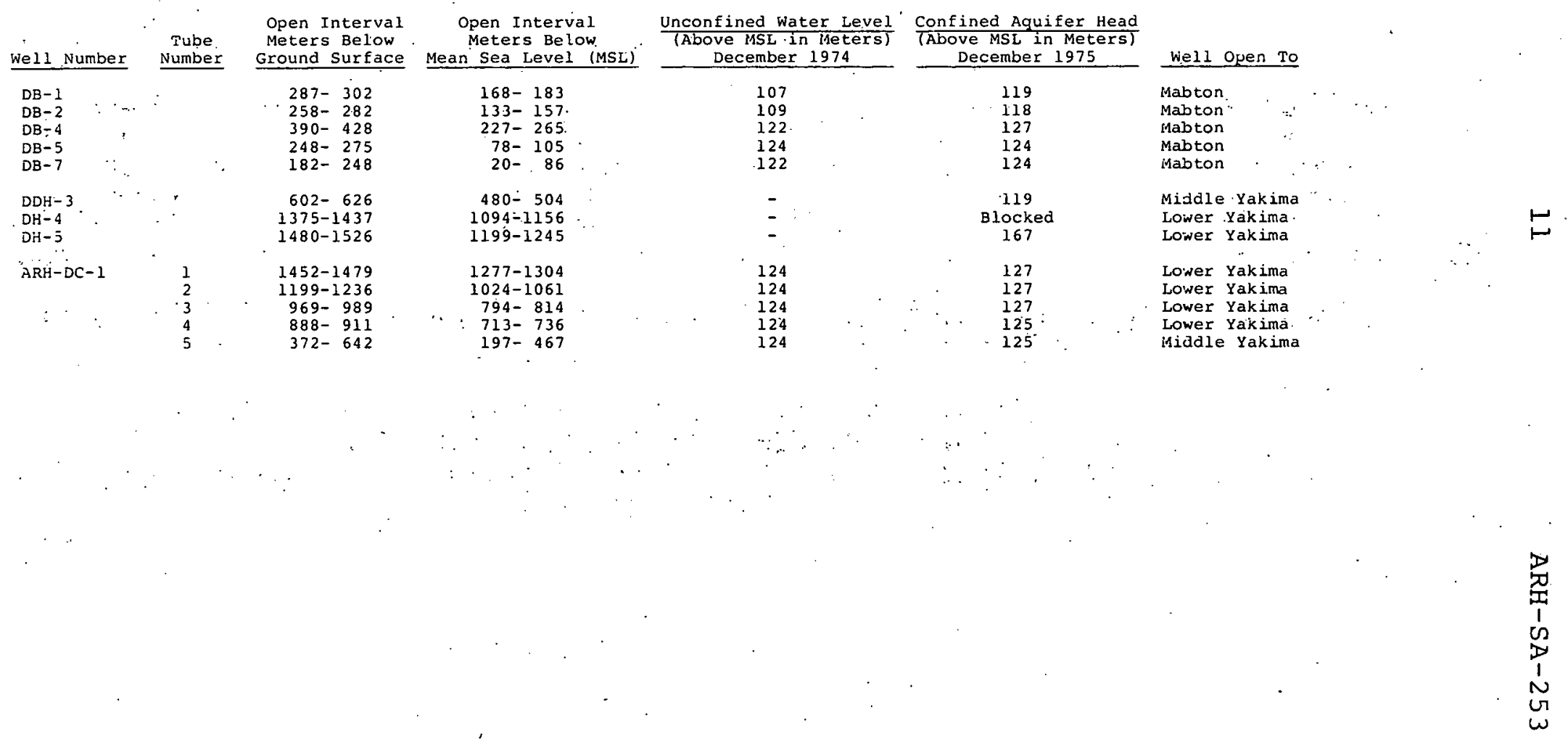


TABLE IV

MONITORING WELLS OUTSIDE THE HANFORD RESERVATION SUITABLE FOR HEAD MEASUREMENTS AND CHEMICAL. SAMPLING

(Refer to Figure 3 . for Well Locations)

Well Number

$\begin{array}{ll}11 / 29-16 A 1 & \text { (Sunset) } \\ 11 / 29-20 N 1 & \text { (White Bluffs) } \\ 12 / 29-30 J 1 & \text { (Webber) } \\ 12 / 29-32 \mathrm{Rl} & \text { (Ringold) } \\ 14 / 24-21 B 1 & \text { (Army 93-93) } \\ 14 / 25-31 M 1 & \text { (Army 79-104) }\end{array}$

11/29-16Al (Sunset)

11/29-20Nl (White Bluffs)

14/25-31MI (Army 79-104)
Open Interval

Meters Below Ground Surface
Confined Aquifer Head Above MSI in Meters

\section{$-\star$}

$-\star$

$-*$

123

120
Well, Open To.

Upper Yakima

Upper Yakima

Upper Yakima

Upper Yakima

$131-207$

*Wells have pumps that do not allow head measurements. 


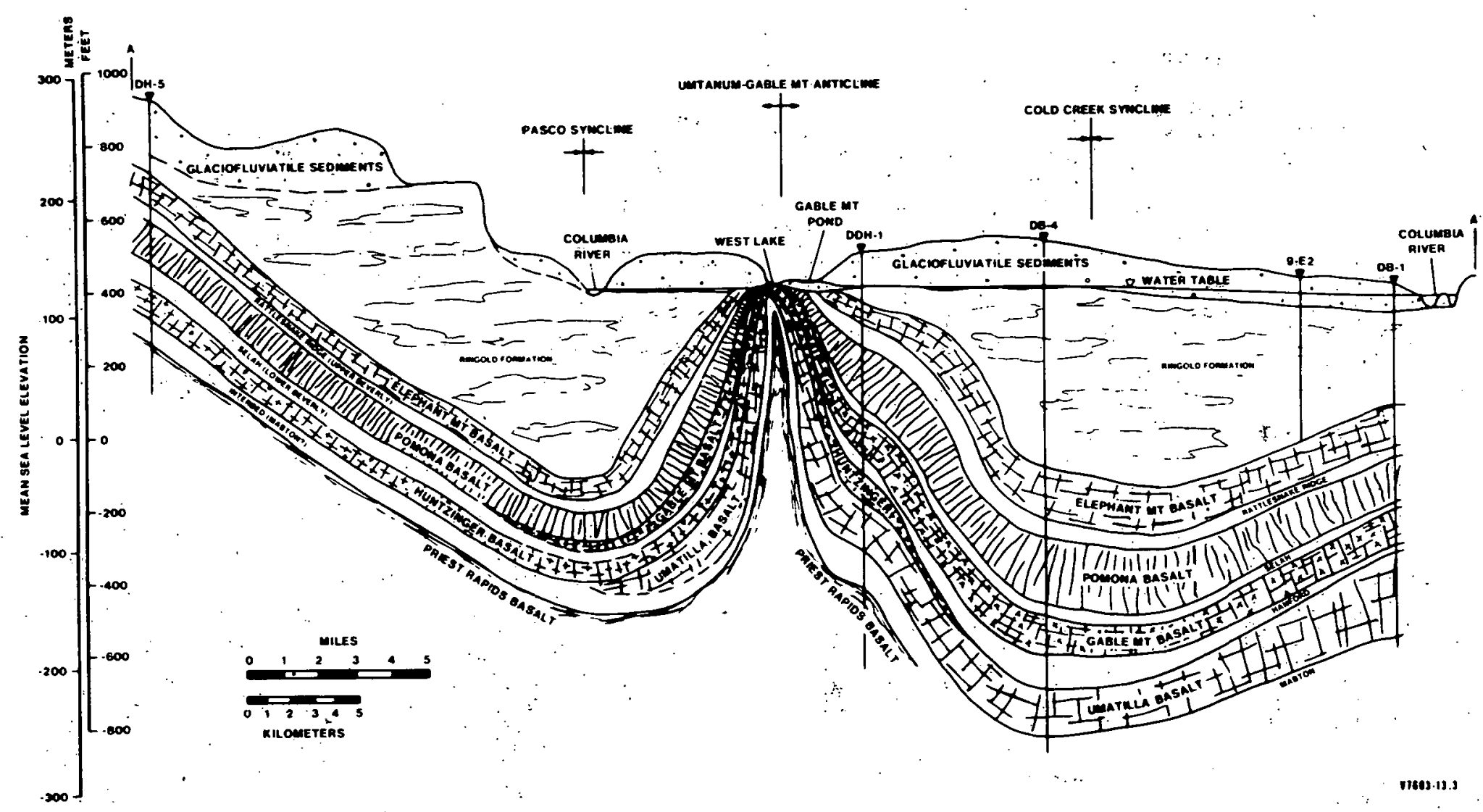

FIGURE 4

CROSS-SECTION A-A' 


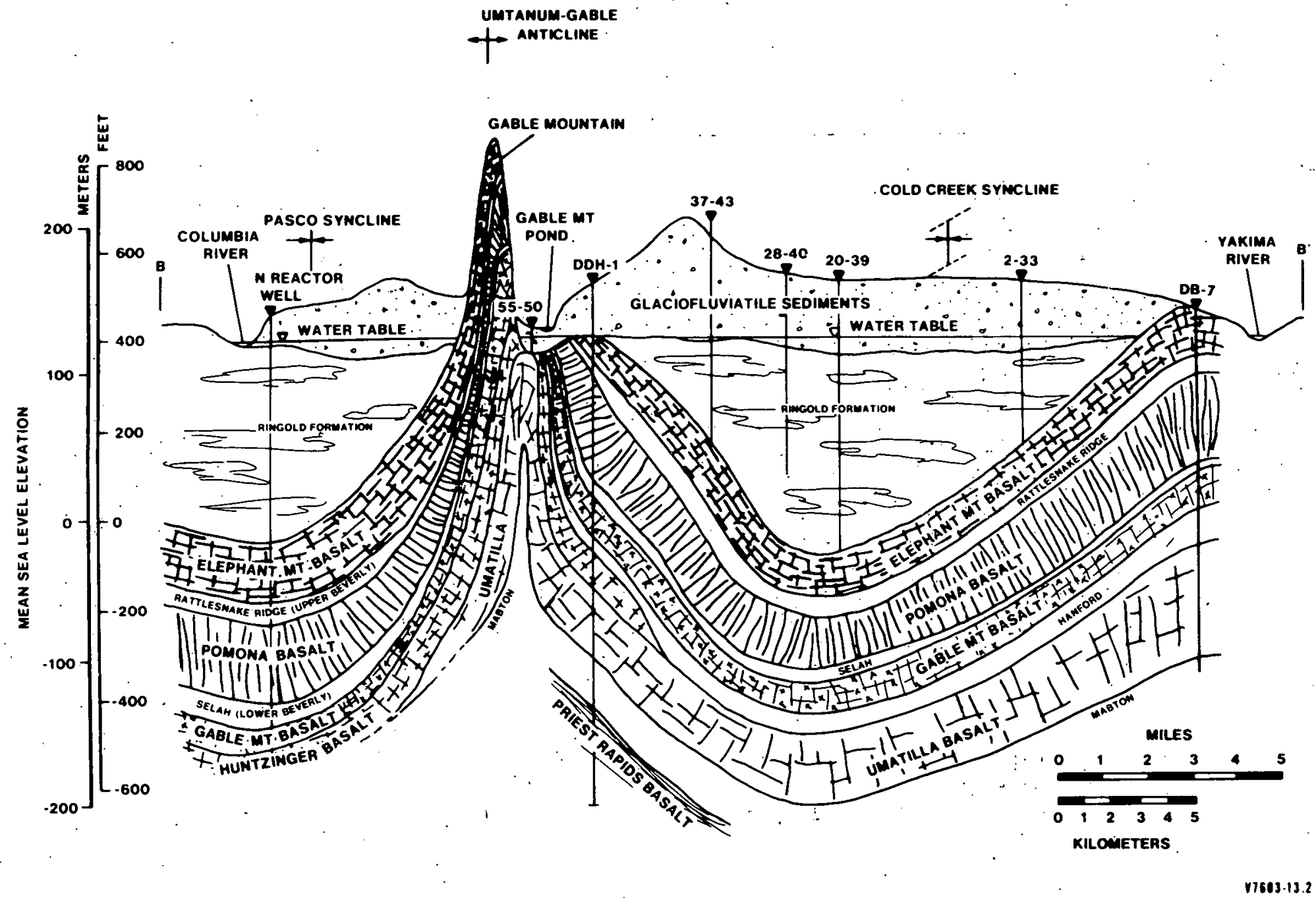

FIGURE 5

CROSS-SECTION B-B' 


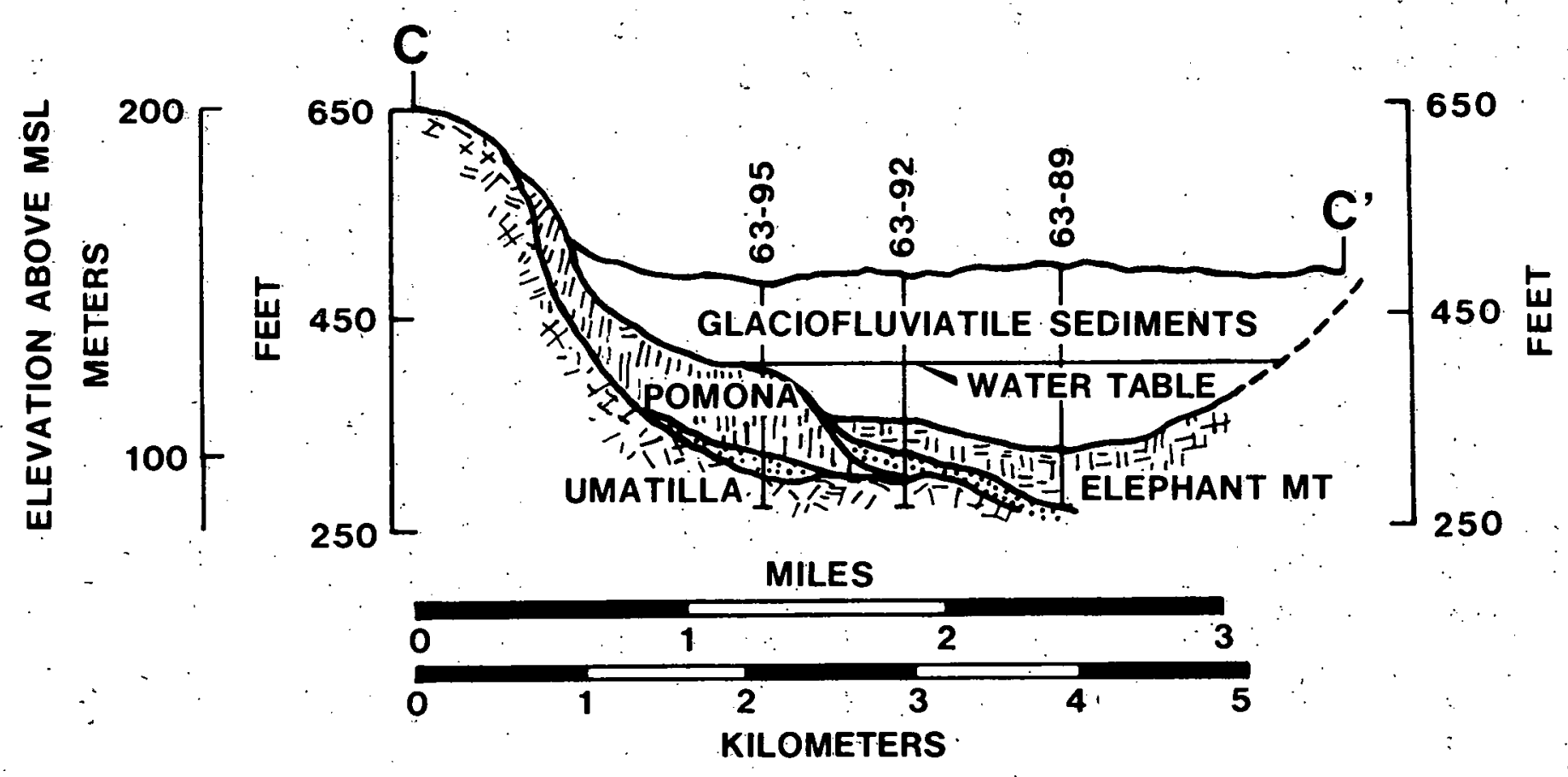

V7603.13.4

FIGURE 6

CROSS-SECTION C-C' 
Anticline and the flanking Pasco and Cold Creek synclines. The flows are reasonably paraliel and continuous and have been strongly affected by lateral compression. Figure 5 shows a north-south cross section from $N$ Reactor through. Gable Mountain to Horn Rapids (Yakima River).”. This cross section shows the possibility of hydraulic interconnection in the area between Gable Mountain and Gable Butte. Glacial flood waters have breached and removed part of the steeply dipping anticlinal structure to the top of the Umatilla basalt flow.

Newcomb et a $2 .[2]$ consider the Horn Rapids area of the Yakima River a recharge area for the uppermost confined aquifers. The Yakima River cuts a smalil anticline breaching the Elephant Mountain Flow and possibly the Pomona Flow. Head..measurements taken during drilling of Well DB-7 (Figure 5 ) appear to confirm equilibrium between the uppermost confined aquifers (down to the Mabton), the unconfined aquifer and the Yakima River.

Figure 6 shows a west-east trending cross section from Umtanum Ridge to Gable Butte. It clearly reveals the pinching out or erosional removal of several basalt flows and interbeds. In this area it appears that this pinching out and the tilting of the flows may cause, one of the interbeds to be hydraulically interconnected with the overlying unconsolidated sediment (unconfined aquifer).

REGIONAL HYDROLOGY

Ground water beneath the Hanford Reservation occurs in either an unconfined flow system consisting of glaciofluviatile or Ringold sediment or in one of several deeper confined aquifers. The regional hydrology of the unconfined 
system has been extensively discussed in previous papers. $[9-10]$ The unconfined aquifer is artificially recharged with liquid waste disposed at five ponds within the Hanford Reservation.

Piezometer data (Figure 7) have been used to demonstrate the nature of the artificial flow systems formed as a result of waste"disposal operations. Equipotential. lines and flow system divides are shown in Figure $7 . \therefore$ The direction of flow in each system is perpendicular to the equipotential lines. The artificial flow systems appear to overlie and interact with the unconfined (intermediate) flow system which, in turn, interacts with the uppermost confined aquifers (regional system).

As noted in the preceding section, the uppermost confined aquifers underlying the Hanford Reservation are the sands and gravels of the Lower Ringold Formation and the Rattlesnake Ridge, Selah, Hanford, and Mabton Interbeds. Some pumping tests have been conducted to determine the hydraulic characteristics of the Lower Ringold Formation and Rattlesnake Ridge Interbeds [10] These tests were conducted mostly in 1.5 -inch $(3.7 .5-\mathrm{cm})$ piezometer tubes within 8-inch $(20-\mathrm{cm})$ casings. All these tests were of short duration and at low production rates. Both production and recovery data were recorded. Transmissivity and hydraulic conductivity values obtained from these tests are given in Table v:

No pumping tests have been conducted in the selah and Hanford aquifers. Information on the hydraulic conductivity and transmissivity of the Mabton Interbed and deeper aquifers is available only from tests on ARH-DC-1. [8] 


\section{VERTICAL EXAGGERATION $=64$ TIMES}

${ }_{x \times x}:$ EQUIPOTENTIAL LINES (FEET)

' FLOW SYSTEM DIVIDES

GROUNDWATER FLOW DIRECTION.
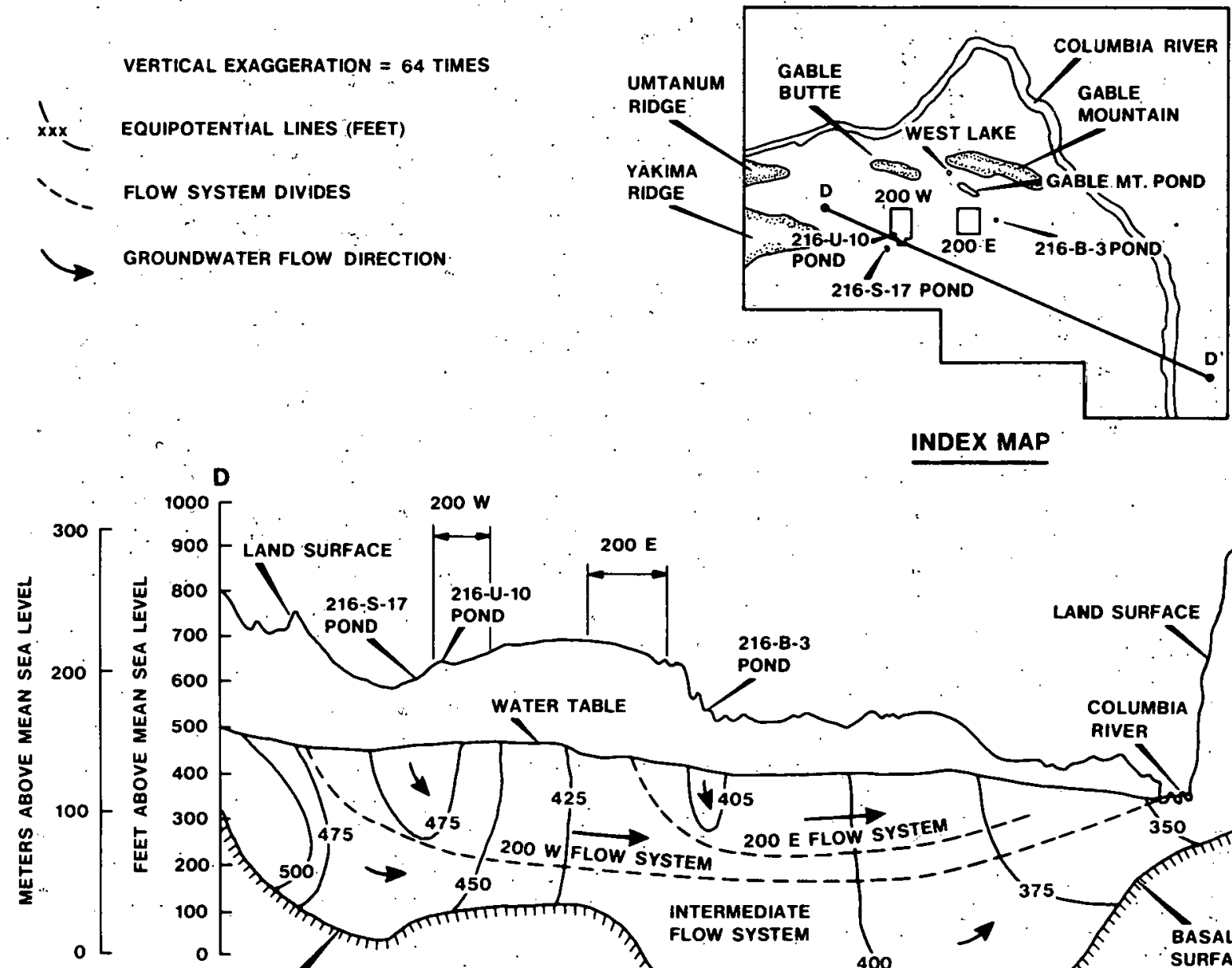

.

1000
900
800
700
600
500
400
300
200
100
0

[ Lan

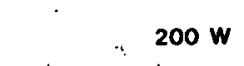


TABLE V.

HYDRAULIC PROPERTIES OF THE

UPPERMOST CONFINED' AQUIFERS

\section{$\frac{\text { Well Number }}{\text { LOWER RINGOLD }}$}

$04-35 P$

699-84-35?

$699-24-1 P$

$699-\mathrm{SII}-\mathrm{E} 12$

699-20-EI P P: :

Mean

Range

4
90
40
350.

120

$4-350$
Transmissivity
H.ydraulic

Conductivity

RATTLESNAKE RIDGE

199-B 3-2P

$199-\mathrm{H} 4-2$

$699-14-\mathrm{E} 6 \mathrm{Q}$

Mean

Range m/day

ft/day

0.11

5

0.5

7

3

$0.11-7$

11

$0.4-32$

$0.03-2.1$
0.03

1.5

0.15

2.1. .

0.91

$\begin{array}{ccccc}3.5 & 0.3 & 0.25 & 0.08 \\ 3 & 0.3 & 0.3 & 0.09 \\ 600 & 55 & 30 & \vdots & 9.1 \\ 200 & 18 & 10 & 3 & 3.0 \\ 3-600 & 0.3-55 & 0.25-30 & 0.08-9.1\end{array}$

MABTON, .

MIDDLE YAKIMA, LOWER YAKIMA

ARH-DC-1 Range $0.1-200$ O.01-18 $0.006-10$ O.002-3:0

All hydraulic conductivity measurements given in Table $V$ refer to the horizontal hydraulic conductivity of the interbeds. The vertical hydraulic conductivity of the interbeds is at least an order of magnitude smaller than the horizontal hydraulic conductivity component. In the flows the main component of hydraulic conductivity is vertical and the horizontal hydraulic conductivity component is negligible: Over most areas of the Hanford Reservation. the overall hydraulic conductivity of each interbed is primarily horizontal and is much greater than that of its overlying and. underlying flows, thus causing water to move laterally in the interbed for long distances. Where this movement is 
restricted by flexures or faults ground water will exist under considerable confining pressure. Such a condition exists on the eastern side of the cold Creek valley where several artesian wells exist. It appears that a tight monoclinal downfold in this area is responsible for this condition.

All of the uppermost confined aquifers down to the Mabton equivalent appear to recharge from ridges and plateaus fringing the Pasco Basin and discharge into the Columbia River or south of the Hanford Reservation near Wallula Gap. It appears probable that the Horse Heaven Hills, an anticlinal ridge at the southern boundary of the Pasco Basin, causes ground water from the uppermost confined aquifers north of these hill's to enter the Columbia River north of Wallula Gap.

Figure 8 shows the piezometric heads of the Lower Ringold, Rattlesnake Ridge, and Mabton as measured in wells throughout the Hanford Reservation. Although the data for the Lower Ringold are limited to wells very near the Columbia River, it appears that along the banks of the River the Lower Ringold aquifer is connected to the overlying unconfined aquifer. The Columbia River probably represents base level drainage for the Lower Ringold aquifer.

In all wells examined, the piezometric levels in the uppermost confined aquifers are higher than or equal to the water level in the unconfined aquifer. It is possible that this situation could be reversed in the 200 west Area due to the higher head in the unconfined aquifer resulting from liquid waste discharges.

An Ice Harbor Flow (Table I) occurs in the extreme. 


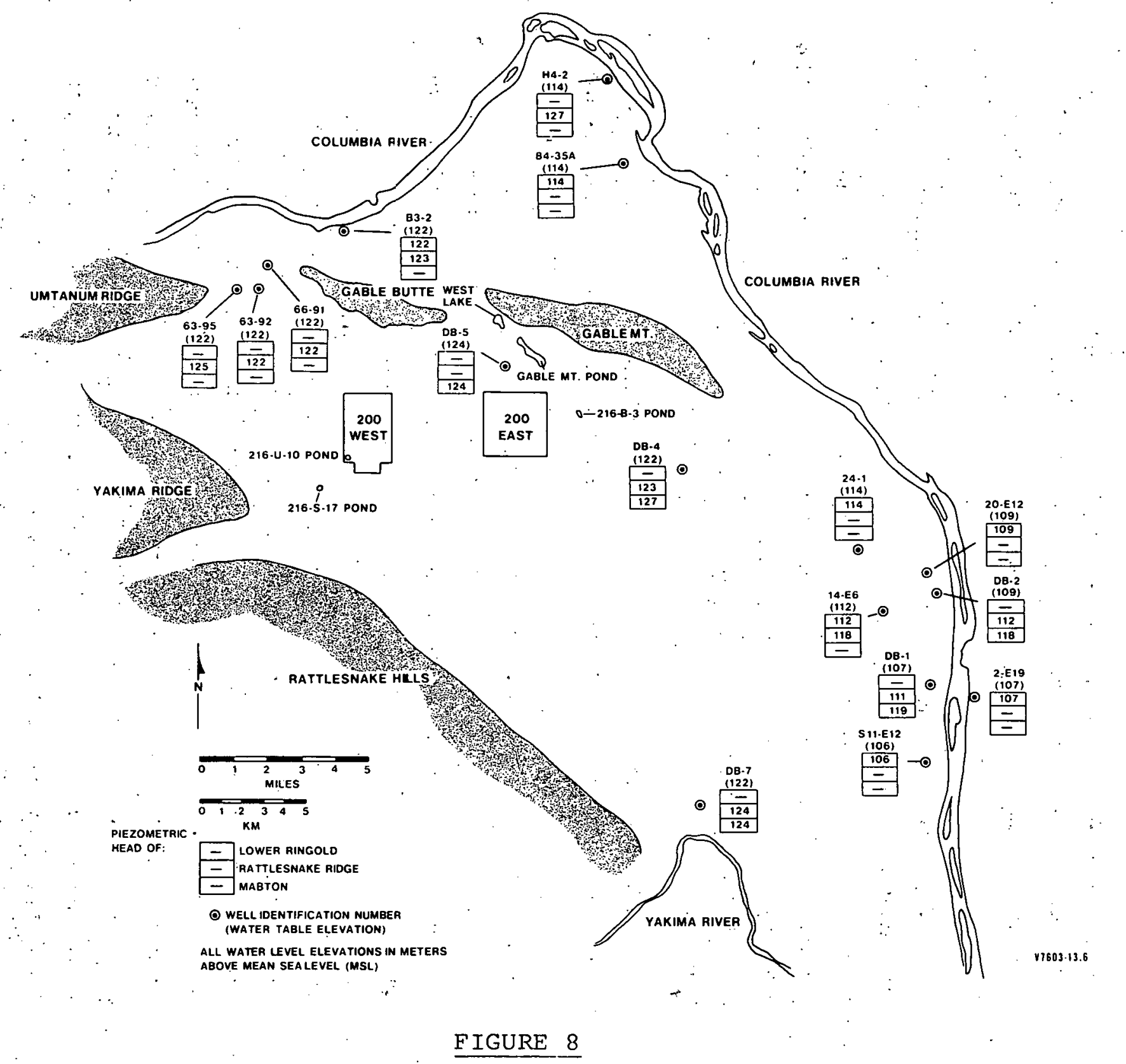


southeast section of the Hanford Reservation associated with an interbed of lapilli tuff and tuffaceous sandstone. The 300 Area (Figure 1) is probably the northwest limit of the flow and interbed. Hydraulic interconnection between this interbed and the Lower Ringold may exist but has not been confirmed.

The Elephant Mountain Member of the upper basalts forms an extensive confining unit in the Pasco Basin. The unit may be continuously traced from the sentinel Gap area through the two Wahluke slope core wells (DH-4 and DH-5), the core wells near $\mathrm{N}$ Reactor, the DB core wells, and across Rattlesnake Ridge to near Yakima where it outcrops at the type locality.

The Elephant Mountain Member is associated with an interbed of tuffaceous or pozzolanic sandstone. This interbed is probably more continuous than all the others and is termed Rattlesnake Ridge from Yakima eastward to Gable Mountain and Upper Beverly at Sentinel Gap. In the area between Gable Butte and Umtanum Ridge the Rattlesnake Ridge is in equilibrium with the Lower Ringold. Data from Well 699-63-95 show the presence of a small confining lens of Rattlesnake Ridge (or possibly the Selah. Interbed) in this area. This lens has a much higher head than the Rattlesnake Ridge and Lower Ringold systems; however its water content is very limited. A production test from this lens yielded very little water. At Well DB-7 by the horn of the Yakima River the Rattlesnake Ridge is in equilibrium with the overlying aquifers. The Rattlesnake Ridge aquifer does not appear to be very productive. Short production tests with minimal yields were conducted in the DB Wells during drilling.

The Pomona Basalt Flow lies below the Elephant Mountain 
Flow and the Rattlesnake Ridge Interbed. It overlies the Selah (Lower Beverly) Interbed. The Selah is only locally important as a domestic water source. It appears to. recharge from fracture systems in the surrounding basalts. Below the Pomona are two members of rather limited extent--the Gable Mountain and Huntzinger. These flows were probably limited to valleys of the central basin and are found with interbeds of tuff and/or tuffaceous sandstone. Below the Gable Mountain member a relatively thick 30-meter interbed of sandstone, clay, and conglomerate exists in the synclinal trough penetrated by well DB-4. This zone caved in and did not yield water under testing procedures. Tests were abandoned to prevent loss of the hole.

The Umatilla Member lies below the Huntzinger. The most extensive confined interbed, the Mabton, lies below the Umatilla Member. This interbed is more than 30 meters thick in some portions of the Pasco Basin. Static water levels in Wells $\mathrm{DB}-1$ and $\mathrm{DB}-2$ penetrating the Mabton Interbed are much higher than the water levels in the unconfined aquifer at these locations. The Mabton is in equilibrium with the Yakima River at Horn Rapids:

Although piezometric data are lacking, one can safely conclude that the eastern portion of the Hanford Reservation is a discharge area for the uppermost confined aquifers. In areas of breaching of the basalt flows or in areas of severe tilting the uppermost confined aquifers will be in hydraulic equilibrium with the overlying unconfined aquifer: Areas of monoclinal downfolding can act as barriers and increase the confining pressure. The uppermost confined aquifers appear to be interconnected along the anticlinal axis or in areas of severe erosion. The head of all the aquifers appears to increase with depth. 


\section{CONCLUSIONS}

The uppermost confined flow systems underlying the Hanford Reservation consist of Pliocene sands of the Lower Ringold Formation and Miocene interbeds between individual members of the Columbia River Basalts. These interbeds appear to have been deposited in lacustrine or fluviatile. environs between successive lava outpourings. The basalts have been subjected to extensive warping and deformation which is especially visible along the Umtanum-Gable Anticline. In the vicinity of this anticline where the flows are severely tilted and where the ancestral Columbia River has deeply eroded the flows, the interbeds are covered with just a thin veneer of glaciofluviatile sediment and are thus locally unconfined. Areas of breaching occur between Umtanum Ridge and Gable Butte and between Gable Butte and Gable Mountain. West Lake (Figure 3) near Gable Mountain pond is probably fed from severely tilted basalt interbeds. Breaching also occurs at the horn of the Yakima River (Fiquire 5).

Recharge into the confined aquifers appears to occur at the fringes of the Pasco Basin. The eastern portion of the Hanford Reservation appears to be a discharge area for these aquifers.

Areas of monoclinal downfolding such as the cold creek valley appear to act as flow barriers, thus helping to build. up the pressure in the uppermost confined aquifers. 


\section{AC KNOWLEDGMENTS}

The authors would like to acknowledge the help of Mr. C. T. Webster of Fenix: \& Scisson, R. E.. Gephart of: Atlantic Richfield Hanford Company, and J.. R. Raymond, Battelle Pacific Northwest Laboratories: All figures were drafted by F.A. Harlow and his staff, Vitro Engineering Division of Automation industries, Inc.

\section{REFERENCES}

1. R. C. Newcomb, Effect of Tectonic Structure on the occurrence of Ground Water in the Basalt of the Columbia River Group near The Dalies, oregon, and Washington, United states Geological Survey Professiónal Paper 383-C. (1969).

2. R. C. Newcomb, J. R. Strand, and F. J. Frank, Geology and Groundwater Characteristics of the Hanford Reservation of the U. S. Atomic Energy Commission, Washington, United States Geological Survey Profes$\therefore$ "sional Paper 717" (1972).

3. R. E. Brown, A study of Reported Faulting in the Pasco Basin, BNWL-662, Battelle Pacific Northwest Laboratories, Richland, Washington (1968):

4. "Basalt Aquifer Identification, Correlation and Sampling Program. Well History: $\mathrm{DB}-1,-2,-4,-5$, \& -7 ; Hanford-Works, Richland, Washington," Fenix \& Scisson, Inc. : Richland, Washington (1974).

5. "Hole History, Core Hole" DDH-3; Hanford Works, Richland, Washington," Fenix \& Scisson, Inc., Tulsa, Oklahoma (1970). 
6. "Hole History, Core Holes $\mathrm{DH}-4$ \& $\mathrm{DH}-5$; Hanford Works, Richland, Washington," Fenix \& Scisson, Inc., Richland, Washington (1972) .

7. "Recovery and Completion Report, Hole ARH-DC-1, Hanford Works, Richland, Washington," Fenix \& Scisson, Inc., Richland, Washington. (1972).

8. A. M. LaSala, Jr., and T. C. Doty; "Preliminary Evaluation of Hydrologic Factors Related to Radioactive Waste Storage in Basaltic Rocks at the Hanford Reservation, Washington," United States Geological Survey Open-File Report (1971).

9. R. A. Deju, "The Hanford Field Testing Program,". RAD-6, RAD Associates, Richland, Washington (1974).

10. R. A. Deju and W. K. Summers, "Transmissivity and Hydraulic Conductivity of Saturated Sedimentary. Rocks in the Hanford Reservation," RAD-5, RAD Associates, Richland, Washington (1975).

11. Environmental Statement of Waste Management Operations, Hanford Reservation, Richland, Washington, WASH-1538, United States Energy Research and Development Administration (1975).

12. S. M. Price, A Geochemical Classification of Dikes of the Grande Ronde Swarm, Columbia River. Basalt, ARH-SA-202, Atlantic Richfield Hanford Company, Richland, Washington (1974).

13. D. A. Swanson et al., "Feeder Dikes for Yakima Basalt Near Pasco, Washington" (abs.) Geological Society of America, Abstracts with Programs, Vol. 4, No. 3 (1972). 
14. B. H. Richard and R. A. Deju, "A Regional Gravity Investigation over the Hanford Reservation," RAD-6; RAD Associates. (1975).

15. "Logs of Exploratory Trenches on Gable Mountain; at the Hanford Works of the U. S. Atomic Energy Commission, Richland, Washington," Converse, Davis, and Associates, Pasadena, California (1969). 